\title{
Isolation and characterization of spirilloid purple phototrophic bacteria forming red layers in microbial mats of Mediterranean salterns: description of Halorhodospira neutriphila sp. nov. and emendation of the genus Halorhodospira
}

\author{
Correspondence \\ Pierre Caumette \\ pierre.caumette@univ-pau.fr
}

\author{
Agnès Hirschler-Réa, ${ }^{1}$ Robert Matheron, ${ }^{1}$ Christine Riffaud, ${ }^{1}$ \\ Sophie Mouné, ${ }^{2,4}$ Claire Eatock, ${ }^{3}$ Rodney A. Herbert, ${ }^{3}$ John C. Willison ${ }^{2}$ \\ and Pierre Caumette ${ }^{4}$ \\ ${ }^{1}$ Laboratoire de Microbiologie, IMEP, Faculté des Sciences et Techniques de Saint Jérôme, \\ 13397 Marseille cedex 20, France \\ ${ }^{2}$ Laboratoire de Biochimie et Biophysique des Systèmes Intégrés, DBMS/BBSI, CEA Grenoble, \\ 38054 Grenoble, France \\ ${ }^{3}$ Division of Environmental and Applied Biology, Biological Sciences Institute, University of \\ Dundee, Dundee DD1 4HN, UK \\ ${ }^{4}$ Laboratoire d'Ecologie Moléculaire-Microbiologie, IBEAS, BP 1155, Université de Pau, \\ F 64013 Pau cedex, France
}

\section{INTRODUCTION}

Spiral cell morphology is widely distributed among several genera of both sulfur and non-sulfur phototrophic purple bacteria. Among the purple non-sulfur bacteria, eight genera composed of spiral-shaped bacteria have been

The EMBL accession numbers for the $16 \mathrm{~S}$ rDNA sequences of Halorhodospira neutriphila strains SG $3301^{\top}$ and SG 3304 are AJ318525 and AJ318526, respectively. described: Rhodospirillum, Phaeospirillum, Rhodovibrio, Rhodothalassium, Roseospira (Imhoff et al., 1998), Rhodocista (Kawasaki et al., 1992; Favinger et al., 1989), Rhodospira (Pfennig et al., 1997) and Roseospirillum (Glaeser \& Overmann, 1999). Among the purple sulfur bacteria, spiral-shaped bacteria are present in the Chromatiaceae (Thiospirillum) and the Ectothiorhodospiraceae as exemplified by the genera Ectothiorhodospira, Halorhodospira and Thiorhodospira (Imhoff \& Süling, 1996; Bryantseva et al., 1999). 
The majority of these bacteria require salt for optimal growth except for members of the genera Rhodospirillum, Phaeospirillum, Rhodocista and Thiospirillum. The saltrequiring bacteria have been isolated from coastal marine environments or inland salt lakes. Several have been isolated from hypersaline environments and described as moderately halophilic bacteria belonging to the genera Rhodovibrio, Rhodothalassium, Roseospira and Ectothiorhodospira. Only a few strains have been described as extreme halophiles and have been included in a single genus, Halorhodospira. Among all these spiral-shaped phototrophic moderate or extreme halophilic bacteria, a number have been isolated from sediment layers or deposits in hypersaline ponds or salt flats in evaporitic coastal environments. Within the purple non-sulfur bacteria, Rhodospirillum salexigens (Drews, 1981), later renamed Rhodothalassium salexigens (Imhoff et al., 1998), was isolated from hypersaline evaporated pools on the Oregon coast, USA, and Rhodospirillum salinarum (Nissen \& Dundas, 1984), later renamed Rhodovibrio salinarum (Imhoff et al., 1998), was isolated from a Portuguese saltern. Similarly, among the purple sulfur bacteria Ectothiorhodospira mobilis (Trüper, 1968) was isolated from evaporitic salt flats in the Galapagos Islands. Other moderately to extremely halophilic purple sulfur or non-sulfur bacteria have been isolated from inland salt lakes or the Dead Sea.

During our investigation of microbial mats that develop in some lagoons within commercial salterns in the Rhône Delta (France), we observed a purple layer composed mainly of spiral-shaped bacteria below a thin gypsum crust. A number of strains were isolated and characterized. According to phenotypic and phylogenetic features, strain SG 3105 was related to Rhodovibrio sodomensis which was originally isolated by Mack et al. (1993) from the Dead Sea. The other isolated strains, SG $3301^{\mathrm{T}}$, SG 3302 and SG 3304, were also characterized. According to physiological and phylogenetic features these strains are closely related to the genus Halorhodospira that contains extreme halophilic species isolated from inland salt lakes or the Dead Sea (Imhoff et al., 1998). However, none of the strains could be related to any currently described species of this genus. They are described in this paper together with Rhodovibrio sodomensis strain SG 3105 which was isolated from the same layer using the same growth medium. Strains SG $3301^{\mathrm{T}}$, SG 3302 and SG 3304 represent a new species within the genus Halorhodospira for which we propose the name Halorhodospira neutriphila sp. nov. Strain SG $3301^{\mathrm{T}}$ $\left(=\mathrm{DSM} 15116^{\mathrm{T}}\right)$ is the type strain of the species.

\section{METHODS}

Source of strains. All the spirilloid strains (SG 3301 ${ }^{\mathrm{T}}$, SG 3302, SG 3304 and SG 3105) were isolated from the same red layer occurring immediately below a green layer of cyanobacteria in a laminated microbial mat in the hypersaline lagoons (Etang de Faraman) of the Salin-de-Giraud, a commercial saltern in the Camargue (Rhône Delta, France). This laminated mat was found below a thin gypsum crust periodically covered by halite deposits. The salinity of the pond water ranges from 240 to $320 \%$ of total salinity. From October to June lower salinities (240-280\%) occur. During the summer months (June to September) the salinity increases up to $320 \%$, resulting in the deposition of halite; during this period, the microbial mats disappeared. The strains were isolated from samples collected when the microbial mats were fully developed in May to June.

Media, isolation and culture conditions. The strains were isolated from enrichment cultures of red-layer samples. The enrichment medium was prepared according to Pfennig \& Trüper (1992). It contained ( $1^{-1}$ distilled water): $\mathrm{KH}_{2} \mathrm{PO}_{4}, 1 \mathrm{~g} ; \mathrm{CaCl}_{2} .2 \mathrm{H}_{2} \mathrm{O}, 0 \cdot 05 \mathrm{~g}$; $\mathrm{NH}_{4} \mathrm{Cl}, 0.5 \mathrm{~g} ; \mathrm{NaCl}, 100 \mathrm{~g} ; \mathrm{MgCl}_{2} \cdot 6 \mathrm{H}_{2} \mathrm{O}, 2 \mathrm{~g} ; \mathrm{MgSO}_{4} .7 \mathrm{H}_{2} \mathrm{O}, 1 \mathrm{~g}$; $\mathrm{NaHCO}_{3}, 2 \mathrm{~g} ; \mathrm{Na}_{2} \mathrm{~S} .9 \mathrm{H}_{2} \mathrm{O}, 0.75 \mathrm{~g}$; vitamin solution $\mathrm{V} 7,1 \mathrm{ml}$; trace element solution SL12, $1 \mathrm{ml}$. The $\mathrm{pH}$ was adjusted to $\mathrm{pH} 7 \cdot 2-7 \cdot 4$. For enrichments and for better growth of pure cultures, the growth medium was supplemented with acetate $(2 \mathrm{mM})$, succinate $(1 \mathrm{mM})$ and yeast extract $\left(0 \cdot 5 \mathrm{~g} \mathrm{l}^{-1}\right)$.

Pure cultures were obtained after isolation from a deep-agar shake dilution series prepared according to the method of Pfennig \& Trüper (1992) and incubated at $30^{\circ} \mathrm{C}$ and at a light intensity of 500 lux from a tungsten lamp ( $16 \mathrm{~h}$ light, $8 \mathrm{~h}$ dark). Purity of cultures was checked by both microscopic observation and growth tests in deep agar AC medium (Difco) supplemented with $\mathrm{NaCl}$ and thiosulfate (final concentrations 10 and $0.05 \%$, w/v, respectively) and incubated in the dark. Pure cultures in liquid medium were stored in $60 \mathrm{ml}$ screw cap bottles at $4{ }^{\circ} \mathrm{C}$ in the dark.

Microscopy. Microscopic observations and photomicrographs were made with a Zeiss photomicroscope according to the method of Pfennig \& Wagener (1986). Flagella were observed by transmission electron microscopy (TEM) after negative staining with $1 \%(\mathrm{w} / \mathrm{v})$ tungstic acid neutralized to $\mathrm{pH} 7 \cdot 2$ (JEOL 1200 EX electron microscope). The fine structure of the cells was studied by TEM after fixation of a cell pellet with osmic acid and ultrathin sectioning of the cells according to Reynolds (1963).

Pigment analysis and DNA base composition. Absorption spectra of living cells were measured with a Kontron spectrophotometer (UVIKON 860) after suspension of a cell pellet in sucrose solution (Pfennig \& Trüper, 1992). Carotenoids were extracted and separated by TLC according to the method described by Eichler \& Pfennig (1986). They were determined by comparison with several standards.

The $\mathrm{G}+\mathrm{C}$ content of the DNA was determined by HPLC as described by Mesbah et al. (1989), using bacteriophage $\lambda$ DNA as the standard.

165 rDNA sequence. Isolation of genomic DNA, amplification of $16 \mathrm{~S}$ rDNA by PCR, sequencing and phylogenetic analysis were all carried out as described previously (Mouné et al., 1999, 2000). The accession numbers of all $16 \mathrm{~S}$ rDNA sequences used in this study are given in Fig. 4.

Physiological tests. Utilization of carbon sources and electron donors was tested in the basal liquid medium supplemented with $1 \mathrm{mM} \mathrm{Na} \mathrm{Sa}_{2} .9 \mathrm{H}_{2} \mathrm{O}$ and using substrate concentrations as given in Table 1 .

Growth tests of utilizable substrates, the determination of optimal concentrations of $\mathrm{NaCl}$ and $\mathrm{MgCl}_{2}$ and the determination of optimal $\mathrm{pH}$, light intensity and sulfide tolerance were performed in completely filled $25 \mathrm{ml}$ screw cap tubes. Growth was measured by determining the $\mathrm{OD}_{650}$ (Spectronic 20; Bausch and Lomb) over a 15 day period.

Micro-aerophilic growth was tested in uniformly inoculated deep agar tubes open to air and incubated in the dark at $25^{\circ} \mathrm{C}$ (Kämpf \& 
Table 1. Utilization of substrates as electron donors or carbon sources by strains SG $3301^{\top}$, SG 3302, SG 3304 and SG 3105

+ , Utilized; (+), poorly utilized; - , not utilized. The following substrates were not utilized by the four strains: thiosulfate $(5 \mathrm{mM})$, sulfite $(1 \mathrm{mM})$, formate $(5 \mathrm{mM})$, citrate $(5 \mathrm{mM})$, caprylate $(2 \mathrm{mM})$, pelargonate $(2 \mathrm{mM})$, palmitate $(2 \mathrm{mM})$, benzoate $(2 \mathrm{mM})$, tartrate $(5 \mathrm{mM})$, nicotinate $(2 \mathrm{mM})$, glucose $(5 \mathrm{mM})$, fructose $(5 \mathrm{mM})$, sucrose $(5 \mathrm{mM})$, trehalose $(5 \mathrm{mM})$, methanol $(5 \mathrm{mM})$, ethanol $(5 \mathrm{mM})$, propanol $(5 \mathrm{mM})$, butanol $(5 \mathrm{mM})$, mannitol $(5 \mathrm{mM})$, glycerol $(5 \mathrm{mM})$, peptone $(0.05 \%)$, cysteine $(2 \mathrm{mM})$, methionine $(2 \mathrm{mM})$, thioglycolate $(2 \mathrm{mM})$ and thioacetamide $(2 \mathrm{mM})$.

\begin{tabular}{|lcccc|}
\hline Substrate $^{*}$ & SG 3301 $^{\text {T }}$ & SG 3302 & SG 3304 & SG 3105 \\
\hline Sulfide $(3 \mathrm{mM})$ & $(+)$ & $(+)$ & $(+)$ & - \\
Elemental sulfur & $(+)$ & $(+)$ & $(+)$ & - \\
$\quad(0 \cdot 05 \%)$ & & & & \\
Acetate & + & + & + & + \\
Propionate & - & + & + & + \\
Butyrate & - & - & - & + \\
Valerate & - & - & - & + \\
Crotonate & - & - & - & + \\
Lactate & - & - & - & + \\
Pyruvate & + & + & + & + \\
Malate & - & - & - & + \\
Fumarate & + & + & + & - \\
Succinate & + & + & + & + \\
2-Oxoglutarate & - & - & - & + \\
Glycolate & - & - & - & + \\
Betaine & - & - & - & + \\
Gluconate & - & - & - & + \\
Aspartate & - & - & - & + \\
Glutamate & - & - & - & + \\
Casamino acids & - & - & - & + \\
$\quad(0 \cdot 05 \%)$ & & & & + \\
Yeast extract & + & - & - & + \\
$\quad(0 \cdot 05 \%)$ & & & & + \\
\hline
\end{tabular}

^The concentration was $5 \mathrm{mM}$ unless otherwise indicated.

Pfennig, 1980). Vitamin requirement and capacity for assimilatory sulfate reduction were tested in $60 \mathrm{ml}$ screw cap bottles by growth tests through four consecutive transfers in synthetic liquid media free of vitamins and yeast extract or sulfide, respectively.

Nitrogen sources were tested in $60 \mathrm{ml}$ aluminium cap sealed bottles with gas-impermeable butyl rubber septum stoppers filled one-third with liquid medium without nitrogen sources and supplemented with $10 \mathrm{mM}$ acetate, and two-thirds with argon as gas phase. The tested nitrogen sources (ammonia, nitrate, organic nitrogen in cysteine, serine and glutamate) were added prior to inoculation. For nitrogen fixation, the gas phase was replaced by $\mathrm{N}_{2}$ gas $(100 \mathrm{kPa})$. Growth was tested through four consecutive transfers under the same conditions.

Hydrogen utilization was tested by the same method in liquid medium without electron donors with only $0.5 \mathrm{mM} \mathrm{Na} \mathrm{Na}_{2} .9 \mathrm{H}_{2} \mathrm{O}$ as sulfur source and with $\mathrm{H}_{2} / \mathrm{CO}_{2}(80: 20, \mathrm{v} / \mathrm{v} ; 100 \mathrm{kPa})$ as the gas phase. The presence of hydrogenase was tested according to the method of Trüper (1968).

Growth on sulfide, sulfide $+\mathrm{CO}_{2}$ and on sulfide + acetate was tested in 11 cultures grown in synthetic liquid medium for 15 days. Growth was measured periodically by $\mathrm{OD}_{650}$ (Spectronic 20; Bausch and Lomb). Sulfide, sulfur and sulfate concentrations were determined according to the methods of Cline (1969), Stal et al. (1984) and Tabatabaï (1974), respectively.

The presence of catalase was determined by adding a few drops of $3 \%$ (v/v) $\mathrm{H}_{2} \mathrm{O}_{2}$ to $2 \mathrm{ml}$ of a dense cell suspension.

Determination of compatible solutes by ${ }^{13} \mathrm{C}$-NMR spectroscopy. Isolate SG $3301^{\mathrm{T}}$ was grown as an 81 batch culture in synthetic growth medium supplemented with $2 \mathrm{mM}$ acetate and $1 \mathrm{mM}$ succinate plus $15 \%(\mathrm{w} / \mathrm{v}) \mathrm{NaCl}$ but without yeast extract. Cultures were incubated at room temperature $\left(25^{\circ} \mathrm{C}\right)$ in the light and continuously sparged with oxygen-free nitrogen to maintain anaerobic conditions. Mid-exponential phase $\left(\mathrm{OD}_{650}=0 \cdot 4\right)$ cultures were harvested, extracted and analysed for compatible solutes by natural abundance NMR according to the methods of Welsh \& Herbert (1994).

\section{RESULTS}

\section{Description of microbial mats and isolation of pure strains}

Thin greenish and reddish laminated mats have been observed in particular hypersaline lagoons in the commercial salterns in the Salin-de-Giraud (Camargue, France) (Cornée, 1983; Caumette et al., 1988, 1991, 1994). These mats are present for most of the year and are fully developed in spring and summer, from May to September. The thickest mats (10-20 mm thick) were observed at the sediment surface of a series of lagoons below a $2-3 \mathrm{~cm}$ thick gypsum crust. In these lagoons the salinity of the water column (20-40 cm depth) ranged from 130 to $200 \%$. These microbial mats consisted principally of a green layer of cyanobacteria overlying a purple layer of phototrophic sulfur bacteria belonging to the family Chromatiaceae (Caumette et al., 1988, 1991, 1994).

In contrast, in other lagoons with higher water salinities ranging from 200 to $320 \%$, the gypsum crust at the sediment surface was thinner $(2-5 \mathrm{~mm}$ thick) and it was periodically covered by halite crystals when the salinity increased above $300 \%$. In these lagoons, from May to June, a laminated mat developed at the sediment surface, below the gypsum crust. The sediment was composed of a closed anoxic system containing high amounts of AVS (total acidvolatile sulfide) up to $20-40 \mathrm{mmol} \mathrm{kg}{ }^{-1}$ (Caumette et al., $1991,1994)$. When the salinity increased up to $300 \%$ in July, the mat decreased gradually and then disappeared by the end of the summer. This mat consisted mainly of a green layer of cyanobacteria (Phormidium-like). Below this layer, a red layer occurred. Microscopic observations revealed the sole presence of actively motile spirilloid cells that formed the red layers (Fig. 1). Free sulfur globules were also present and distributed in the entire layer. From red layer samples, enrichment cultures of spirilloid purple sulfur bacteria 


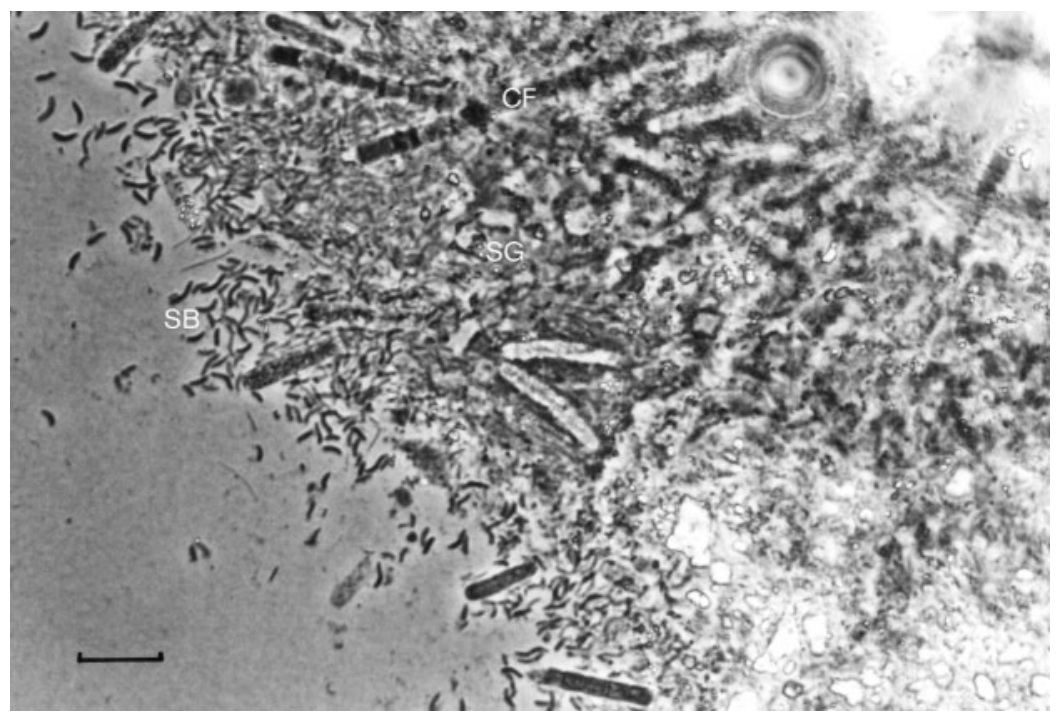

Fig. 1. Photomicrograph of the purple layer of the microbial mat below the gypsum crust at the sediment surface of the sampling site in the Salin-de-Giraud salterns. Note the presence of filamentous cyanobacteria (CF), many vibrioid to spirilloid bacterial cells (SB) and sulfur globules (SG) in the mat. Bar, $10 \mu \mathrm{m}$.
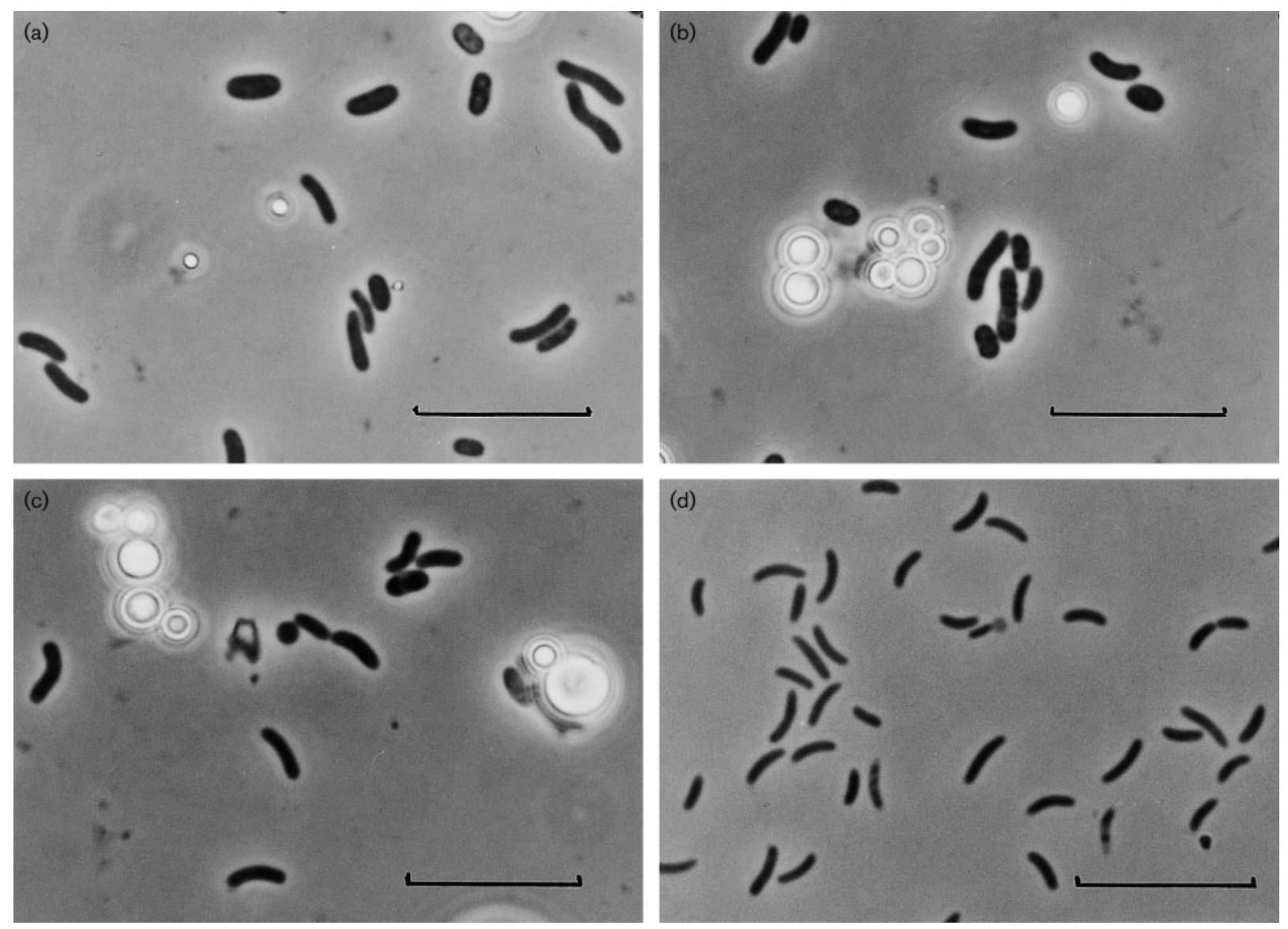

Fig. 2. Phase-contrast micrographs of strains SG $3301^{\top}$ (a), SG 3302 (b), SG 3304 (c) and SG 3105 (d). Bars, $10 \mu \mathrm{m}$.

were obtained. Several strains were then isolated in the same synthetic growth medium with $10 \%(\mathrm{w} / \mathrm{v}) \mathrm{NaCl}$. Four strains (SG 3301 ${ }^{\mathrm{T}}$, SG 3302, SG 3304 and SG 3105) were isolated, maintained in pure culture and characterized.

\section{Description of the isolated strains}

Morphology. When examined by phase-contrast microscopy, three strains (SG $3301^{\mathrm{T}}$, SG 3302 and SG 3304) exhibited a similar morphology consisting of actively 
motile curved rods, $2-5 \mu \mathrm{m}$ long and $1 \cdot 0-1 \cdot 2 \mu \mathrm{m}$ wide. When grown with sulfide, sulfur globules were present in the growth medium, outside the cells (Fig. 2a, b and c). In the presence of acetate or succinate, some larger noncurved cells containing reserve material (PHB) occurred with a width of $1 \cdot 4-1 \cdot 6 \mu \mathrm{m}$. The morphology of strain SG 3105 consisted of motile spirilloid cells of $2-4 \mu \mathrm{m}$ length and $0.5-0.6 \mu \mathrm{m}$ width. In contrast to the other strains, sulfur globules were never observed in the growth medium of strain SG 3105 (Fig. 2d). The cells of all strains divided by binary fission.

Pigments. For strains SG $3301^{\mathrm{T}}$, SG 3302 and SG 3304, the colour of the cell suspensions were identical, pink to pinkish-red. As shown in the absorption spectra of the living cells (Fig. 3a, b), cells of strains $S G 3301^{\mathrm{T}}$ and SG 3304, and also SG 3302 (not shown), contained similar pigments: BChl $a$ with absorption maxima at 376, 589, 786-787 and 883-884 nm; carotenoids of the normal spirilloxanthin series with absorption maxima at 486-488, 519-520 and $556 \mathrm{~nm}$. Spirilloxanthin was the dominant

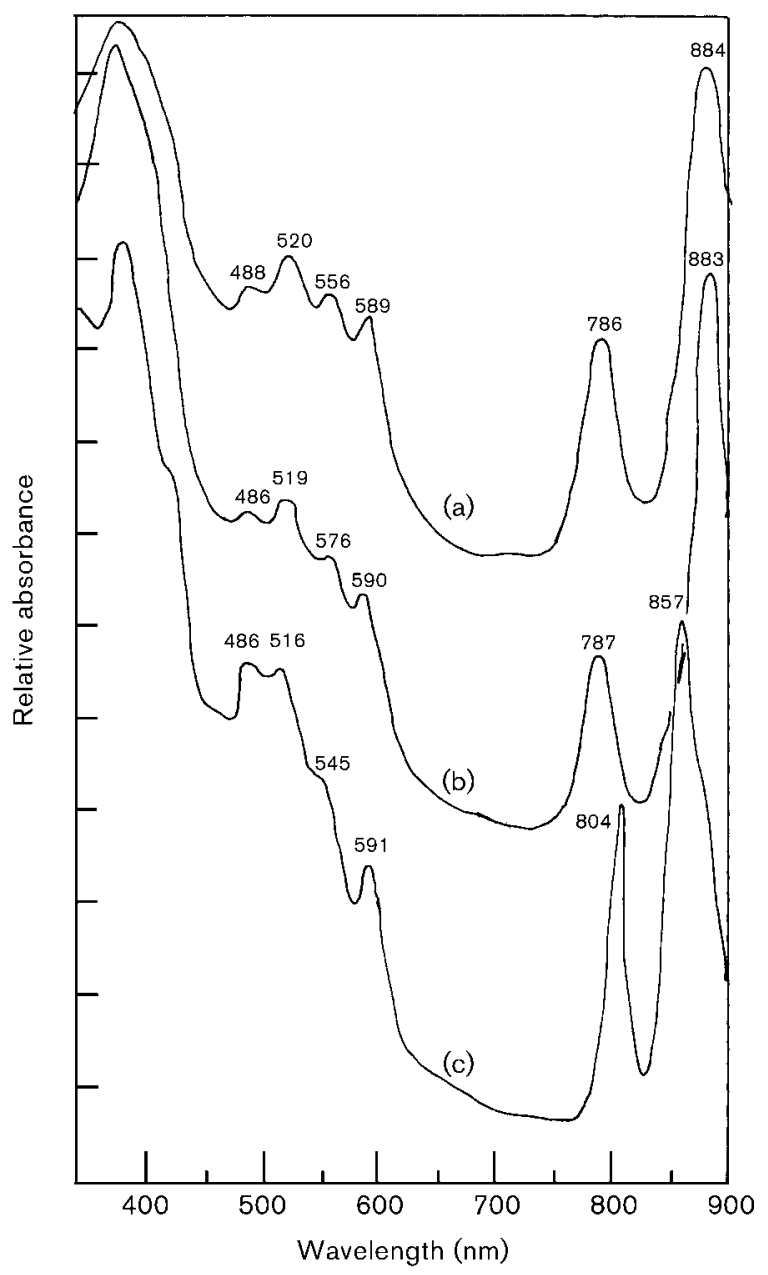

Fig. 3. Absorption spectra of living cells of strain SG $3301^{\top}$ (a), SG 3304 (b) and SG 3105 (c). carotenoid present as determined by TLC. The colour of the cell suspension of strain SG 3105 was red to brownred. Absorption spectra of whole cells (Fig. 3c) showed maxima at 379, 591, 804 and $857 \mathrm{~nm}$ typical for BChl a containing cells, and at 486, 516 and a shoulder at $545 \mathrm{~nm}$, indicative of the presence of carotenoids of the normal spirilloxanthin series. The absorption maximum at $486 \mathrm{~nm}$ indicated the presence of rhodopin as a major carotenoid pigment and this was confirmed by TLC.

Substrate utilization by the four strains. Substrate utilization tests were performed for strains SG $3301^{\mathrm{T}}$, SG 3302 , SG 3304 and SG 3105 (Table 1). Three strains, SG 3301 , SG 3302 and SG 3304, were able to weakly use sulfide and sulfur. However, with these compounds as electron donors and $\mathrm{CO}_{2}$ as sole carbon source, the growth of the three isolates was very poor. In contrast all three strains showed good growth with a limited range of organic substrates as electron donors and carbon sources: pyruvate, fumarate, succinate, acetate and for certain strains, propionate and yeast extract. Strain SG 3105 is an obligate photoorganotroph and able to use a large variety of organic substrates (Table 1).

Effect of salt on the growth of the four strains. The four strains SG $3301^{\mathrm{T}}$, SG 3302, SG 3304 and SG 3105 grew at $\mathrm{NaCl}$ concentrations ranging from 6-8\% to 25-30\% (w/v) NaCl. The optima for all strains ranged from 9 to $12 \%(\mathrm{w} / \mathrm{v}) \mathrm{NaCl}$. These results demonstrate a good adaptation of the strains to their environment where the total salinity of 240-320\% corresponds approximately to $17-25 \%(\mathrm{w} / \mathrm{v}) \mathrm{NaCl}$ in the overlying water.

The requirement for $\mathrm{Mg}^{2+}$ was tested for the four strains, between 0 and $200 \mathrm{mM} \mathrm{Mg}^{2+}$. Strains SG $3301^{\mathrm{T}}$, SG 3302 and SG 3304 required a minimum of $0.5 \mathrm{mM}$ with optimal growth recorded at 50,100 and $20 \mathrm{mM}$ respectively. Strain SG 3105 required at least $7.5 \mathrm{mM}$ for growth with an optimum at $100 \mathrm{mM}$. None of the isolates showed improved growth at $\mathrm{Mg}^{2+}$ concentrations above the optimum concentrations for growth.

Genetic properties and 16S rDNA sequences of the isolated strains. The $\mathrm{G}+\mathrm{C}$ of the DNA of strains $\mathrm{SG}$ $3301^{\mathrm{T}}$, SG 3304 and SG 3105 was $74 \cdot 5,74 \cdot 1$ and $69 \cdot 2 \mathrm{~mol} \%$, respectively.

The phylogenetic trees obtained from the comparison of $16 \mathrm{~S}$ rDNA sequences are presented in Fig. $4(\mathrm{a}, \mathrm{b})$. The sequence of Fig. 4(a) shows the phylogenetic tree obtained for strain SG 3105 and the closest sequences. According to the homologies, this strain is closely related to the species Rhodovibrio sodomensis ( $98 \cdot 8 \%$ similarity). Fig. 4(b) shows the phylogenetic tree obtained for the sequences of strains SG $3301^{\mathrm{T}}$ and SG 3304 among the closest sequences. These two strains are identical (100\% homology) among the genus Halorhodospira and close to Halorhodospira halophila DSM $244^{\mathrm{T}}(94.6 \%$ similarity) which is the type species 
(a)

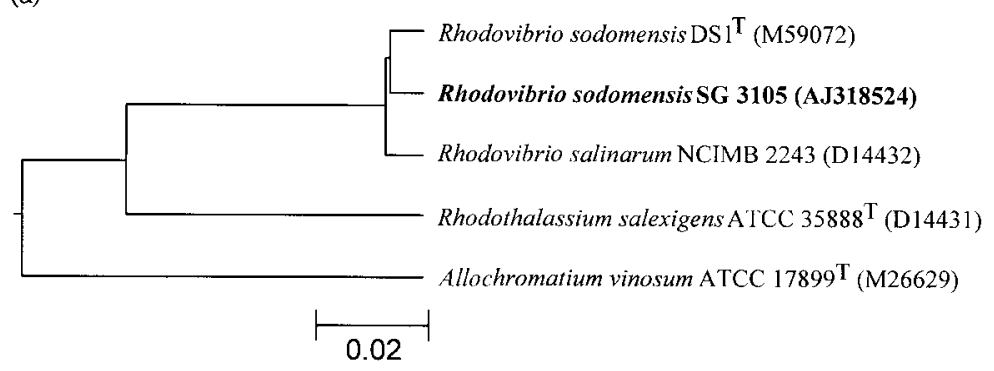

(b)
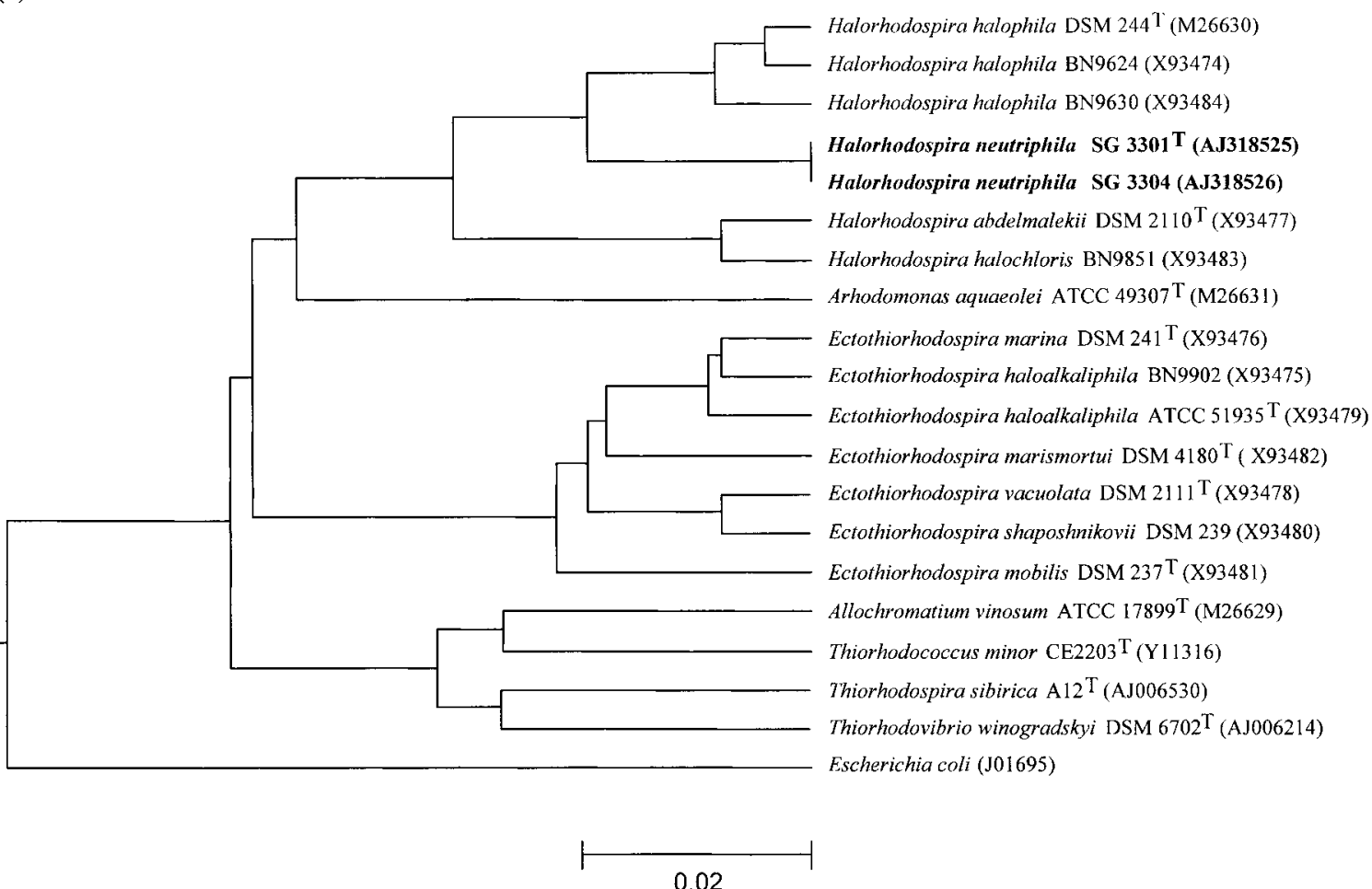

Fig. 4. (a) Phylogenetic position of Rhodovibrio sodomensis strain SG 3105 in relation to other Rhodovibrio and selected other organisms. Scale bar represents 2 nt substitutions per $100 \mathrm{nt}$. (b) Phylogenetic position of strains SG $3301^{\top}$ and SG 3304 in relation to Halorhodospira and selected other organisms. Scale bar represents 2 nt substitutions per 100 nt. $16 \mathrm{~S}$ DNA accession numbers are given for each strain in parentheses.

of the genus. The other two strains of the species (BN 9624 and BN 9630) are less closely related to our strain, with percentage similarities of 91.4 and $90.7 \%$, respectively. These percentage similarities indicate that strains SG $3301^{\mathrm{T}}$ and SG 3304 are sufficiently distant from $H$. halophila to be considered as representatives of a new species.

\section{Additional characteristics of strains SG $3301^{\top}$ and SG 3304}

Electron microscopy. Fig. 5(a, b) shows electron micrographs of whole cells after negative staining (Fig. 5a) and a thin section of the cells of strain SG $3301^{\mathrm{T}}$ (Fig. 5b). The cells are polarly flagellated with a tuft of a few flagella. Thin sections of the cells revealed the presence of an intracellular membrane system comprising stacks of lamellar membranes.

Nitrogen and sulfur sources. Strains SG $3301^{\mathrm{T}}$ and SG 3304 were only able to use $\mathrm{NH}_{4}^{+}$and $\mathrm{N}_{2}$ as nitrogen sources. With nitrate, serine or glutamate as sole nitrogen source, no growth was observed.

Cysteine served as sulfur source in the absence of sulfide. With sulfate as sole sulfur source, growth did not occur, indicating the absence of sulfate reduction.

Micro-aerophilic growth. Growth of strain SG $3301^{\mathrm{T}}$ and SG 3304 was very poor or absent under micro-aerophilic conditions in the dark. Catalase was positive. 

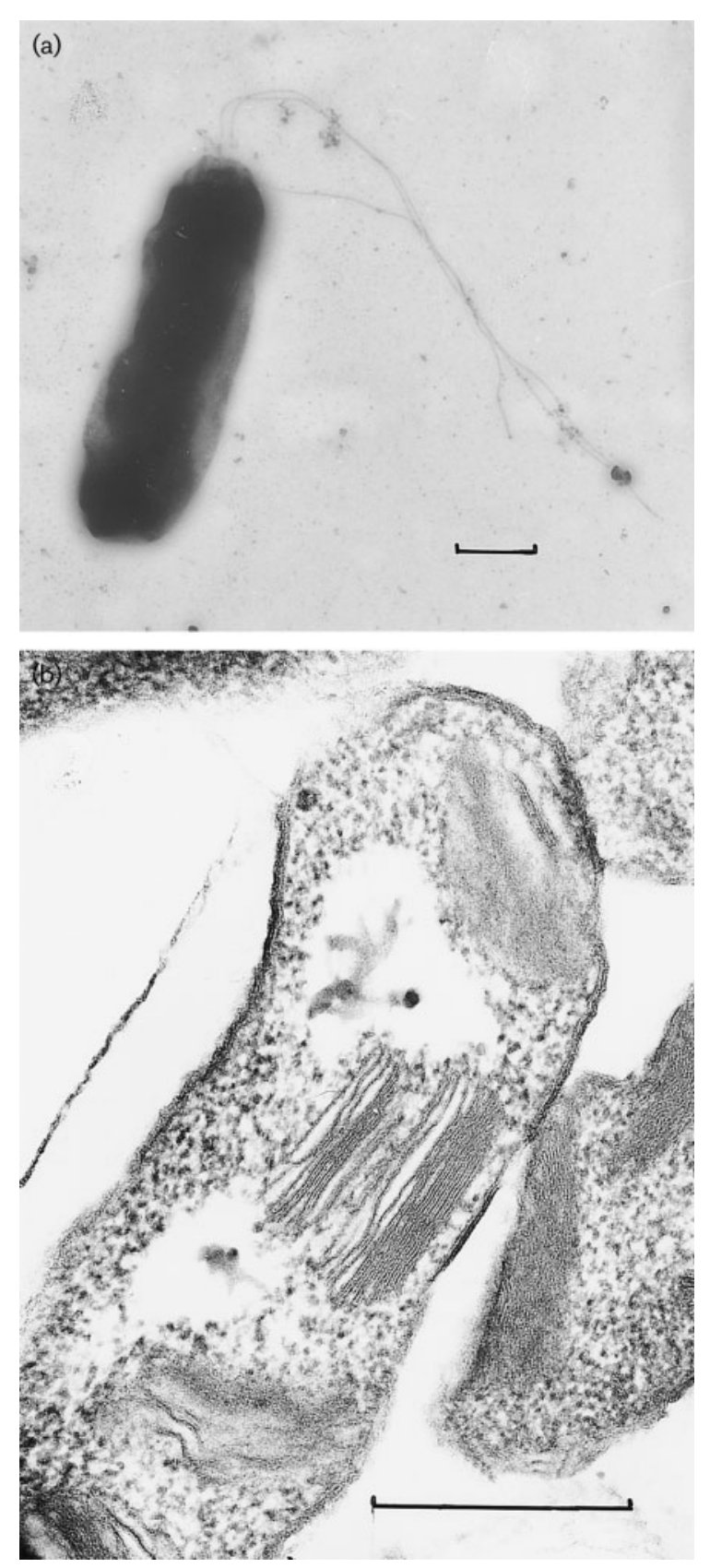

Fig. 5. Electron microscopy and fine structure of Halorhodospira strain SG $3301^{\top}$. (a) Negative staining showing polar flagella. Bar, $1 \mu \mathrm{m}$. (b) Ultrathin section of the cells showing the intracellular stacks of lamellar membranes and envelopes of the Gram-negative type. Bar, $0.5 \mu \mathrm{m}$.

pH, light. Strains SG $3301^{\mathrm{T}}$ and SG 3304 grew in media with a $\mathrm{pH}$ between 6 and $8 \cdot 5$. The optimum $\mathrm{pH}$ was $6 \cdot 8-7 \cdot 0$ for both strains. Growth at different light intensities was determined between 25 and 5000 lux using a tungsten lamp light source. For both isolates growth was very slow at 25 lux. Optimal light intensity was recorded at 5000 lux for both strains with growth rates of
$0.034 \mathrm{~h}^{-1}$ for strain SG3301 and $0.01 \mathrm{~h}^{-1}$ for strain SG 3304 under optimal conditions.

$\mathrm{H}_{2}$ and vitamin requirements. Both strains SG $3301^{\mathrm{T}}$ and SG 3304 were unable to grow with $\mathrm{H}_{2}$ as sole electron donor. In addition, hydrogenase activity was tested and the result was negative for both strains.

Both strains were able to grow in synthetic growth medium in the absence of vitamins or yeast extract after five consecutive transfers, indicating that neither isolate had a vitamin requirement.

Sulfide tolerance and utilization of sulfur compounds as electron donors. Strains SG $3301^{\mathrm{T}}$ and SG 3304 were able to grow with up to $5 \cdot 5-6 \mathrm{mM}$ sulfide in the synthetic growth medium. The optimum was $1-3 \mathrm{mM}$ for both strains. For strain SG $3301^{\mathrm{T}}$, with optimum sulfide, in the presence of $\mathrm{CO}_{2}$ as sole carbon source, growth was always very poor, although sulfide and the produced sulfur were completely oxidized to sulfate (Fig. 6a). In contrast with acetate as electron donor and carbon source, growth was always very good and the equivalent amount of sulfide and produced sulfur were also completely oxidized to sulfate (Fig. 6b). Sulfide could therefore be considered as a good electron donor for this strain, with or without an organic substrate, even though growth with sulfide and $\mathrm{CO}_{2}$ alone was very poor. This observation indicates that $\mathrm{CO}_{2}$ alone only supported limited growth of strain SG $3301^{\mathrm{T}}$, as shown in Table 2. Maximal growth was obtained with sulfide, acetate and $\mathrm{CO}_{2}$ as substrates in the growth medium.

Identification of compatible solutes. Strain SG $3301^{\mathrm{T}}$ grew optimally in medium containing $12 \%(\mathrm{w} / \mathrm{v}) \mathrm{NaCl}$. At supra-optimal salt concentrations growth progressively decreased due to an increased lag phase and decrease in growth rate (data not shown). Natural abundance ${ }^{13} \mathrm{C}$ spectra of extracts prepared from strain SG $3301^{\mathrm{T}}$ grown in medium containing $15 \%(\mathrm{w} / \mathrm{v}) \mathrm{NaCl}$, but in the absence of yeast extract, showed strong signals at $53 \cdot 70$, 66.52 and 169.58 p.p.m. which correspond to authentic glycine betaine. In addition signals at $18 \cdot 46,21 \cdot 70,37 \cdot 46$, $53 \cdot 70,66 \cdot 52$ and $177 \cdot 02$ p.p.m. were also present which correspond to the osmolyte ectoine. Semi-quantitative estimation (based on peak height) of the identified osmolytes indicate that glycine betaine was the major osmoticum present and ectoine the minor component.

\section{DISCUSSION}

Spirilloid purple bacteria are relatively common in the photic anoxic zones of marine and hypersaline environments. It is perhaps not surprising to observe these microorganisms in microbial mats that develop in marine salterns. In this study, we isolated both purple sulfur and purple nonsulfur bacteria from the same purple layer in a microbial mat occurring below a gypsum crust at total salinities of about 240 to $320 \%$. All the isolated strains grew between 


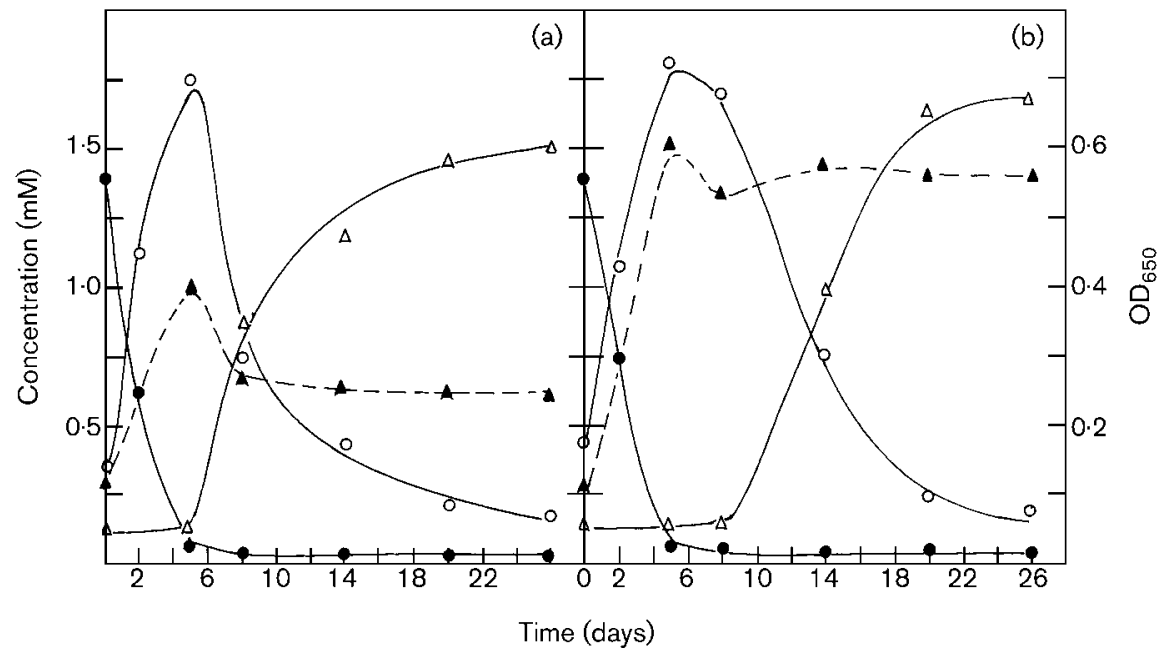

Fig. 6. Production of sulfide, sulfur and sulfate during growth of Halorhodospira strain SG $3301^{\top}$ (a) with $\mathrm{CO}_{2}$ as sole carbon source and sulfide as sole electron donor and (b) with acetate plus $\mathrm{CO}_{2}$ as carbon sources, and acetate plus sulfide as electron donors. Filled circle, sulfide; open circle, sulfur; open triangle, sulfate; filled triangle, $\mathrm{OD}_{650}$.
6-8 and $25-30 \%(\mathrm{w} / \mathrm{v}) \mathrm{NaCl}$ in the synthetic growth medium with optima at 9-12\% (w/v) $\mathrm{NaCl}$. Thus all strains can be considered as strictly halophilic to extremely halophilic bacteria (Caumette et al., 1999). Among these strains, the purple non-sulfur bacterium strain SG 3105 showed characteristics of the genus Rhodovibrio (Imhoff et al., 1998) and was more closely related to Rhodovibrio sodomensis on a physiological and phylogenetical basis, rather than to Rhodovibrio salinarum. This latter organism has been isolated from marine salterns (Nissen \& Dundas, 1984) like our strain. In contrast Rhodovibrio sodomensis was first isolated from a hypersaline pond close to the Dead Sea (Mack et al., 1993). Thus our strain represents the first member of this species isolated from a marine saltern.

In this study, the three other isolated spirilloid strains (SG $3301^{\mathrm{T}}$, SG 3302 and SG 3304) deposited sulfur globules extracellularly when grown with sulfide as electron donor. Morphologically, physiologically and phylogenetically they are fully included in the family Ectothiorhodospiraceae. This family is composed of three genera: Ectothiorhodospira,

Table 2. Growth of Halorhodospira strain SG $3301^{\top}$ in mineral medium supplemented with $\mathrm{CO}_{2}$ or acetate

Growth was measured as $\mathrm{OD}_{650}$ after 15 days (mean of duplicates).

\begin{tabular}{|ll|}
\hline Medium & OD $_{\mathbf{6 5 0}}$ \\
\hline Mineral medium without $\mathrm{CO}_{2}$ & \\
No supplement & $0 \cdot 01$ \\
Sulfide $(2 \mathrm{mM})$ & $0 \cdot 01$ \\
Acetate $(10 \mathrm{mM})$ & $0 \cdot 58$ \\
Mineral medium with $\mathrm{CO}_{2}$ & \\
No supplement & 0 \\
Sulfide $(2 \mathrm{mM})$ & $0 \cdot 12$ \\
Acetate $(10 \mathrm{mM})$ & $0 \cdot 66$ \\
Acetate $(10 \mathrm{mM})+$ sulfide $(2 \mathrm{mM})$ & $0 \cdot 82$ \\
\hline
\end{tabular}

Halorhodospira and Thiorhodospira (Imhoff \& Süling, 1996; Bryantseva et al., 1999). Our three isolated strains were more closely related to the genus Halorhodospira according to the phylogenetic tree based on comparison of $16 \mathrm{~S}$ rDNA sequences. The genus Halorhodospira comprises the most halophilic and alkaliphilic representatives of the Ectothiorhodospiraceae, isolated from athalassohaline environments like the representative of the genus Thiorhodospira. In contrast, members of the genus Ectothiorhodospira have been isolated principally from coastal marine environments at neutral $\mathrm{pH}$ and at lower salinity, although some representatives are alkaliphilic and have been isolated from soda lakes (Imhoff \& Süling, 1996). Therefore, our three strains which are extremely halophilic are the first members of the genus Halorhodospira isolated from marine salterns and living at neutral $\mathrm{pH}$, thus showing that a moderate to extreme salt requirement is an important factor in bacterial taxonomy at the genus level, rather than $\mathrm{pH}$.

All previous isolations of Halorhodospira spp. and Rhodovibrio sodomensis have been from enclosed hypersaline lakes. This study is the first to demonstrate their presence in a modified marine environment, indicating that they have a wider distribution than previously considered. The presence of these populations in the same depth horizon within the mats suggests that both populations are living in same conditions and possible interactions may be occurring. Evidence to support this conclusion is the ability of the purple sulfur Halorhodospira isolates to preferentially use low-molecular-mass organic substrates for growth rather than reduced sulfur compounds. This characteristic is more typical for the photoheterotrophic growth of Rhodovibrio sodomensis.

The salinity range for growth of the strains indicates that all these isolates are well adapted to life in the hypersaline lagoons from which they were isolated. Data presented in this study show that strain SG $3301^{\mathrm{T}}$ when grown at supra-optimal salt concentrations $(15 \%, \mathrm{w} / \mathrm{v}, \mathrm{NaCl})$ in the absence of yeast extract synthesized glycine betaine and 
Table 3. Major properties and differences between Halorhodospira species

+ , Utilized; $(+)$, poorly utilized; \pm , not utilized by this strain but can be utilized by other strains of this species; -, not utilized. All four species are vibrioid in shape, have a stacked internal membrane system and can use pyruvate and acetate.

\begin{tabular}{|c|c|c|c|c|}
\hline Character & $\begin{array}{c}\text { Hlr. neutriphila } \\
\text { sp. nov. SG } 3301^{\mathrm{T}}\end{array}$ & $\begin{array}{c}\text { Hlr. halophila } \\
\text { DSM } 244^{T_{\star}}\end{array}$ & $\begin{array}{l}\text { Hlr. abdelmalekii } \\
\text { DSM } 2110^{\mathrm{T}} \dagger\end{array}$ & $\begin{array}{c}\text { Hlr. halochloris } \\
\text { DSM 1059 }\end{array}$ \\
\hline Cell size (width $\times$ length, $\mu \mathrm{m})$ & $1-1 \cdot 2 \times 2-5$ & $0 \cdot 6-0 \cdot 9 \times 2-8$ & $0 \cdot 9-1 \cdot 2 \times 4-6$ & $0 \cdot 5-0 \cdot 6 \times 2 \cdot 5-8 \cdot 0$ \\
\hline BChl & $a$ & $a$ & $b$ & $b$ \\
\hline Carotenoids & Spirilloxanthin & Spirilloxanthin & Rhodopin & Rhodopin \\
\hline Optimal $\mathrm{NaCl}(\%)$ & 12 & $11-22$ & $14-16$ & $14-25$ \\
\hline Optimal pH & $6 \cdot 8-7 \cdot 0$ & $8 \cdot 5-9 \cdot 0$ & $8 \cdot 0-9 \cdot 2$ & $8 \cdot 1-9 \cdot 1$ \\
\hline Sulfate assimilation & - & - & - & + \\
\hline $\mathrm{G}+\mathrm{C}(\mathrm{mol} \%)$ & $74 \cdot 5$ (HPLC) & $67 \cdot 5-69 \cdot 7\left(T_{\mathrm{m}}\right)$ & $63 \cdot 3-63 \cdot 8\left(T_{\mathrm{m}}\right)$ & $50 \cdot 5-52 \cdot 9\left(T_{\mathrm{m}}\right)$ \\
\hline Sulfide used & $(+)$ & + & + & + \\
\hline Sulfur used & $(+)$ & + & + & + \\
\hline Malate & - & + & + & + \\
\hline
\end{tabular}

${ }^{\star}$ Data from Raymond \& Sistrom (1969) and Pfennig \& Trüper (1989).

†Data from Imhoff \& Trüper (1981) and Pfennig \& Trüper (1989).

$\ddagger$ Data from Imhoff \& Trüper (1977) and Pfennig \& Trüper (1989).

ectoine as compatible solutes. Semi-quantitative estimation of the relative amounts of the accumulated osmolytes indicate that glycine betaine was the major osmoticum synthesized by this isolate and ectoine was the minor component. These data are in agreement with those of Severin et al. (1992) who showed that Halorhodospira halochloris, Halorhodospira abdelmalekii and Halorhodospira halophila also synthesized glycine betaine and ectoine when subjected to salt stress. Strain SG $3301^{\mathrm{T}}$ grows more rapidly when yeast extract is added to the growth medium. Since yeast extract contains significant amounts of glycine betaine (Dulaney et al., 1968) this suggests that strain SG $3301^{\mathrm{T}}$ may possess a functional glycine betaine uptake system. In hypersaline lagoons glycine betaine may account for $>20 \%$ of the total nitrogen present in the mats (King, 1988). Thus, from an ecological viewpoint the ability of an organism to accumulate a compatible solute such as glycine betaine would be advantageous since it is energetically more favourable than synthesis.

Among the Halorhodospira species, our strains (SG $3301^{\mathrm{T}}$ and SG 3304) are related to Halorhodospira halophila according to the rDNA sequence. However, the degree of similarity $(94.6 \%$ similarity) is not sufficiently high to include these isolates within the species Halorhodospira halophila. Physiologically, strain SG $3301^{\mathrm{T}}$ has several characteristics close to the Halorhodospira halophila type strain (DSM $244^{\mathrm{T}}$, Table 3). Both strains contain BChl $a$ and spirilloxanthin as the major carotenoid and have higher $\mathrm{G}+\mathrm{C}$ contents in their DNA, whereas the two other Halorhodospira species (Halorhodospira abdelmalekii and Halorhodospira halochloris) are different with $\mathrm{BChl} b$ and rhodopin as the major photopigments, and a lower $\mathrm{G}+\mathrm{C}$ content in their DNA. However, Halorhodospira strain SG $3301^{\mathrm{T}}$ differs from Halorhodospira halophila by its flagella pattern with one polar tuft rather than bipolar flagellation for Halorhodospira halophila and also for other Halorhodospira (Table 3). Their DNA G $+\mathrm{C}$ content ratios are also different with $74.5 \mathrm{~mol} \%$ for strain SG $3301^{\mathrm{T}}$ and $67 \cdot 5-69 \cdot 7 \mathrm{~mol} \%$ for Halorhodospira halophila. There are also additional physiological differences between both micro-organisms. Halorhodospira halophila is able to use thiosulfate and malate as electron donor whereas Halorhodospira strain SG $3301^{\mathrm{T}}$, is unable to use these substrates and grows poorly on all other sulfur compounds, which is not an usual characteristic of the purple sulfur bacteria. The most important difference between strain SG $3301^{\mathrm{T}}$ and Halorhodospira halophila is the optimal pH for growth. All Halorhodospira species are alkaliphilic with $\mathrm{pH}$ optima between $8 \cdot 0$ and $9 \cdot 0$. In contrast, strain SG $3301^{\mathrm{T}}$ grows optimally at neutral $\mathrm{pH}(6 \cdot 8-7 \cdot 0)$ like other isolated strains (SG 3302 and SG 3304). The three isolated strains are all very similar. According to their morphological, physiological and genetic differences with the described species in the genus Halorhodospira, it is justifiable to consider the three strains as members of a new 
species for which the name Halorhodospira neutriphila sp. nov. is proposed with respect to their optimal growth at neutral $\mathrm{pH}$. Strain $\mathrm{SG} 3301^{\mathrm{T}}$ is proposed as the type strain of this new species.

\section{Emended description of the genus Halorhodospira}

The description of the genus Halorhodospira is as given by Imhoff \& Süling (1996), but with the following additional features: motile by polar tuft of flagella; growth is dependent on saline conditions and neutral or alkaline $\mathrm{pH}$. Halorhodospira species are found in hypersaline and extremely saline environments with neutral to extremely alkaline $\mathrm{pH}$ that contain sulfide and that are exposed to light, such as salterns, salt flats, salt lakes and soda lakes. The $\mathrm{G}+\mathrm{C}$ content of the DNA is $50 \cdot 5-74 \cdot 5 \mathrm{~mol} \%$.

\section{Description of Halorhodospira neutriphila sp. nov.}

Halorhodospira neutriphila (neu.tri.phi'la. L. adj. neutralis neutral; Gr. adj. philos liking, preferring; N.L. adj. neutriphila preferring neutral $\mathrm{pH}$ ).

Cells are curved rods, $1-1 \cdot 2 \mu \mathrm{m}$ wide and $2-5 \mu \mathrm{m}$ long. Multiplication is by binary fission. Gram-negative. Cells are motile by a polar tuft of flagella. Colour of cell suspension is pinkish-red. Photosynthetic membrane system, present as lamellar stacks, contains $\mathrm{BChl} a$ and spirilloxanthin as the major carotenoid. Electron donors for photoautotrophic growth are sulfide and sulfur. Globules of elemental sulfur are present outside the cells. Photoautotrophic growth is poor. In the presence of sulfide and $\mathrm{CO}_{2}$, acetate, pyruvate, fumarate, succinate and yeast extract are photoassimilated. Propionate can be used by some strains. Not capable of chemolithotrophic or chemo-organotrophic growth. Not capable of assimilatory sulfate reduction. $\mathrm{N}_{2}$ and $\mathrm{NH}_{4}$ serve as nitrogen sources. Cysteine is used as sulfur source. No vitamins are required. Optimal $\mathrm{pH}$, $6 \cdot 8-7 \cdot 0$; $\mathrm{pH}$ range for growth, $6 \cdot 0-8 \cdot 5$; optimal temperature, $30-35^{\circ} \mathrm{C} ; \mathrm{NaCl}$ range is between $6-8$ and $25-30 \%$ (w/v) NaCl; optimal concentration at 9-12\% (w/v) NaCl. $\mathrm{G}+\mathrm{C}$ content of DNA is $74 \cdot 1-74 \cdot 5 \mathrm{~mol} \%$ (HPLC). Habitat is anoxic mud, sediments and microbial mats exposed to light in hypersaline to extreme saline environments, such as coastal salterns with salt concentrations of approximately $20-30 \%(w / v)$. Type strain is SG $3301^{\mathrm{T}}$ (=DSM $15116^{\mathrm{T}}$ ) isolated from a benthic microbial mat in a commercial saltern, Salin-de-Giraud (Camargue, France). The 16S rDNA sequence has been deposited in the EMBL database under the accession number AJ318525. The second strain, SG3304, has also been deposited in the DSMZ as DSM 15115 and its $16 \mathrm{~S}$ rDNA sequence accession number is AJ318526.

\section{ACKNOWLEDGEMENTS}

This work was partly supported by a grant of the French Ministry of Education and Research (MESR, ACC-SV7) and by the MATBIOPOL
European research Project (EC, DG XII, EVK3-1999-00010). The authors thank the 'Compagnie des Salin-de-Giraud' for facilitating access to the salterns for sampling and field experiments.

\section{REFERENCES}

Bryantseva, I., Gorlenko, V. M., Kompantseva, E. I., Imhoff, J. F., Süling, J. \& Mityushina, L. (1999). Thiorhodospira sibirica gen. nov., sp. nov., a new alkaliphilic purple sulfur bacterium from a Siberian soda lake. Int J Syst Bacteriol 49, 697-703.

Caumette, P., Baulaigue, R. \& Matheron, R. (1988). Characterization of Chromatium salexigens sp. nov., a halophilic Chromatiaceae isolated from Mediterranean salinas. Syst Appl Microbiol 10, 284-292.

Caumette, P., Baulaigue, R. \& Matheron, R. (1991). Thiocapsa halophila sp. nov., a new halophilic phototrophic purple sulfur bacterium. Arch Microbiol 155, 170-176.

Caumette, P., Matheron, R., Raymond, N. \& Relexans, J.-C. (1994). Microbial mats in hypersaline ponds of Mediterranean salterns (Salin-de-Giraud, France). FEMS Microbiol Ecol 13, 273-286.

Caumette, P., Matheron, R., Welsh, D. T., Herbert, R. A. \& De Wit, R. (1999). Ecology and osmoadaptation of halophilic Chromatiaceae in hypersaline environments. In The Phototrophic Prokaryotes, pp. 707-713. Edited by G. A. Peschek, W. Loffelhardt \& G. Schmetterer. New York: Kluwer.

Cline, J. D. (1969). Spectrophotometric determination of hydrogen sulfide in natural waters. Limnol Oceanogr 14, 454-458.

Cornée, A. (1983). Sur les bactéries des saumures et des sédiments de marais salants méditerranéens. Importance et rôle sédimentologique. Paris: Documents de Greco, Museum.

Drews, G. (1981). Rhodospirillum salexigens, sp. nov., an obligatory halophilic phototrophic bacterium. Arch Microbiol 130, 325-327.

Dulaney, E. L., Dulaney, D. D. \& Ricks, E. L. (1968). Factors in yeast extract which relieve growth inhibition of bacteria in defined medium of high osmolarity. Dev Ind Microbiol 9, 260-269.

Eichler, B. \& Pfennig, N. (1986). Characterization of a new plateletforming purple bacterium, Amoebobacter pedioformis, sp. nov. Arch Microbiol 146, 295-300.

Favinger, J., Stadtwald, R. \& Gest, H. (1989). Rhodospirillum centenum, sp. nov., a thermotolerant cyst-forming anoxygenic photosynthetic bacterium. Antonie van Leeuwenhoek 55, 291-296.

Glaeser, J. \& Overmann, J. (1999). Selective enrichment and characterization of Roseospirillum parvum, gen. nov. and sp. nov., a new purple non-sulfur bacterium with unusual light adsorption properties. Arch Microbiol 171, 405-416.

Imhoff, J. F. \& Süling, J. (1996). The phylogenetic relationship among Ectothiorhodospiraceae: a re-evaluation of their taxonomy on the basis of $16 \mathrm{~S}$ rDNA analyses. Arch Microbiol 165, 106-113.

Imhoff, J. F. \& Trüper, H. G. (1981). Ectothiorhodospira abdelmalekii sp. nov., a new halophilic and alkaliphilic phototrophic bacterium. Zentbl Bakteriol (C) 2, 228-234.

Imhoff, J. F. \& Trüper, H. G. (1977). Ectothiorhodospira halochloris sp. nov., a new extremely halophilic phototrophic bacterium containing bacteriochlorophyll b. Arch Microbiol 114, 115-121.

Imhoff, J. F., Petri, R. \& Süling, J. (1998). Reclassification of species of the spiral-shaped phototrophic purple non-sulfur bacteria of the $\alpha$-Proteobacteria: description of the new genera Phaeospirillum gen. nov., Rhodovibrio gen. nov., Rhodothalassium gen. nov. and Roseospira gen. nov. as well as transfer of Rhodospirillum fulvum to Phaeospirillum fulvum comb. nov., of Rhodospirillum molischianum to Phaeospirillum molischianum comb. nov., of Rhodospirillum 
salinarum to Rhodovibrio salinarum comb. nov., of Rhodospirillum sodomense to Rhodovibrio sodomensis comb. nov., of Rhodospirillum salexigens to Rhodothalassium salexigens comb. nov. and of Rhodospirillum mediosalinum to Roseospira mediosalina comb. nov. Int J Syst Bacteriol 48, 793-798.

Kämpf, C. \& Pfennig, N. (1980). Capacity of Chromatiaceae for chemotrophic growth. Specific respiration rates of Thiocystis violacea and Chromatium vinosum. Arch Microbiol 127, 125-130.

Kawasaki, H., Hoshino, Y., Kuraishi, H. \& Yamasato, K. (1992). Rhodocista centenaria gen. nov., sp. nov., a cyst-forming anoxygenic photosynthetic bacterium and its phylogenetic position in the Proteobacteria alpha group. J Gen Appl Microbiol 38, 541-551.

King, G. M. (1988). Methanogenesis from methylated amines in a hypersaline algal mat. Appl Environ Microbiol 54, 719-725.

Mack, E. E., Mandelco, L., Wœse, C. R. \& Madigan, T. M. (1993). Rhodospirillum sodomense, sp. nov., a Dead Sea Rhodospirillum species. Arch Microbiol 160, 363-371.

Mesbah, M., Premachandran, U. \& Whitman, W. B. (1989). Precise measurement of the $\mathrm{G}+\mathrm{C}$ content of deoxyribonucleic acid by high-performance liquid chromatography. Int J Syst Bacteriol 39, 159-167.

Mouné, S., Manac'h, N., Hirschler, A., Caumette, P., Willison, J. C. \& Matheron, R. (1999). Haloanaerobacter salinarius sp. nov., a novel halophilic fermentative bacterium that reduces glycine-betaine to trimethylamine with hydrogen or serine as electron donors; emendation of the genus Haloanaerobacter. Int J Syst Bacteriol 49, 103-112.

Mouné, S., Eatock, C., Matheron, R., Willison, J. C., Hirschler, A., Herbert, R. \& Caumette, P. (2000). Orenia salinaria sp. nov., a fermentative bacterium isolated from anaerobic sediments of Mediterranean salterns. Int J Syst Evol Microbiol 50, 721-729.

Nissen, H. \& Dundas, I. D. (1984). Rhodospirillum salinarum sp. nov., a halophilic photosynthetic bacterium isolated from a Portuguese saltern. Arch Microbiol 138, 251-256.
Pfennig, N. \& Trüper, H. G. (1989). Anoxygenic phototrophic bacteria. In Bergey's Manual of Systematic Bacteriology, pp. 1635-1709. Edited by J. T. Staley, M. P. Bryant, N. Pfennig \& J. G. Holt. Baltimore: Williams \& Wilkins.

Pfennig, N. \& Trüper, H. G. (1992). The family Chromatiaceae. In The Prokaryotes, pp. 3200-3221. Edited by A. Balows, H. G. Trüper, M. Dworkin, W. Harder \& K. H. Schleifer. New York: Springer.

Pfennig, N. \& Wagener, S. (1986). An improved method of preparing wet mounts for photomicrographs of microoganisms. J Microbiol Methods 4, 303-306.

Pfennig, N., Lünsdorf, H., Süling, J. \& Imhoff, J. F. (1997). Rhodospira trueperi gen. nov., sp. nov., a new phototrophic Proteobacterium of the alpha group. Arch Microbiol 168, 39-45.

Raymond, J. C. \& Sistrom, W. R. (1969). Ectothiorhodospira halophila: a new species of the genus Ectothiorhodospira. Arch Mikrobiol 69, 121-126.

Reynolds, E. S. (1963). The use of lead citrate at high $\mathrm{pH}$ as an electron opaque stain in electron microscopy. J Cell Biol 17, 208-212.

Severin, J., Wohlfarth, A. \& Galinski, E. A. (1992). The predominant role of recently discovered tetrahydropyrimidines for the osmoadaptation of halophilic eubacteria. J Gen Microbiol 138, 1629-1638.

Stal, L. J., Van Gemerden, H. \& Krumbein, W. E. (1984). The simultaneous assay of chlorophyll and bacteriochlorophyll in natural microbial communities. J Microbiol Methods 2, 295-306.

Tabatabaï, M. A. (1974). Determination of sulfate in water samples. Sulphur Inst J 10, 11-13.

Trüper, H. G. (1968). Ectothiorhodospira mobilis Pelsh, a photosynthetic sulfur bacterium depositing sulfur outside the cells. J Bacteriol 95, 1910-1920.

Welsh, D. T. \& Herbert, R. A. (1994). Identification of organic solutes accumulated in purple and green sulfur bacteria during osmotic stress using natural abundance ${ }^{13} \mathrm{C}$ nuclear magnetic resonance spectroscopy. FEMS Microbiol Ecol 13, 151-158. 